\author{
ОСОБЛИВОСТІ РОЗВИТКУ \\ СВІТОВОГО ГОСПОДАРСТВА ТА МЕВ
}

УДК 338.3

\title{
ECONOMIC PRODUCTIVITY: FACTOR APPROACHES
}

\section{ЕКОНОМІЧНА ПРОДУКТИВНІСТЬ: ФАКТОРНІ ПІДХОДИ}

\section{ЭКОНОМИЧЕСКАЯ ПРОИЗВОДИТЕЛЬНОСТЬ: ФАКТОРНЫЕ ПОДХОДЫ}

\author{
Anton S. Filipenko \\ Doctor of Economics, Professor, Professor of the Department of World Economy and International Economic Relations \\ of the Institute of International Relations of Taras Shevchenko National University of Kyiv, email: \\ anton_filipenko@ukr.net
}

\begin{abstract}
Антон Сергійович Філіпенко
Доктор економічних наук, професор, професор кафедри світового господарства і міжнародних економічних відносин Інституту міжнародних відносин Київського національного університету імені Тараса Шевченка, email: anton_filipenko@ukr.net
\end{abstract}

\section{Антон Сергеевич Филипенко}

Доктор экономических наук, профессор, профессор кафедры мирового хозяйства и международных экономических отношений Института международных отношений Киевского национального университета имени Тараса Шевченко, email: anton_filipenko@ukr.net

\begin{abstract}
The article focuses on economic productivity and have stressed the theory of marginal utility (productivity). In modern researches such aggregate indicators as a total factor productivity and a multifactor productivity prevail. Total Factor Productivity is measured by combining the effects of all there sources used in the production of goods and services (labour, capital, materials, energy, etc.) and dividing it into the output. Multifactor productivity (MFP) is the ratio of total output to a subset of inputs. A subset of inputs might consist of only labour and materials or it could include capital. MFP is the residual contribution to output growth of an industry or economy after calculating the contribution from all its factor inputs. The OECD methodology examines key single-factor (aggregated) indicators of labour and capital productivity, considering total output and costs and, most importantly, the value added, which reflects the real increase in the welfare of the nation.
\end{abstract}

Key words: economic productivity, marginal utility, multifactor, total factor, output, inputs, capital, labor.

Анотація. Стаття присвячена економічній продуктивності та наголошує на граничній корисності. У сучасних дослідженнях продуктивності переважають два головні показники - загальна факторна продуктивність та багатофакторна продуктивність. Загальна факторна продуктивність визначається шляхом вимірювання впливу на економічне зростання капіталу, пращі, матеріалів, енергії тощо та їхнє узагальнення у вигляді одного показника. Багатофакторна продуктивність являє собою частку, яка дорівнює співвідношенню випуску та загальних витрат. Показник витрат може включати працю, матеріали і капітал. Методологія ОЕСР досліджує ключові фактори - праџю $i$ капітал у 
контексті продуктивності, особливу увагу звертаючи на додану вартість як головний показник зростання добробуту.

Ключові слова: економічна продуктивність, гранична корисність, загальна факторна, багатофакторна, капітал, прачя, затрати, випуск, добробут.

Аннотация. Статья посвящена экономической производительности с ударением на предельной полезности. В современных исследованиях преобладают два главных показателя - общая факторная производительность и многофакторная производительность. Общая факторная производительность определяется путем измерения влияния на экономический рост капитала, труда, материалов, энергии и др. и их обобщение в виде одного показателя. Многофакторная производительность представляет собой частное от соотношения выпуска и затрат. Показатель затрат может включать труд, капитал и материальл. Методология ОЭСР исследует ключевые факторы - труд и капитал в контексте производительности, обращая особое внимание на добавленную стоимость как главный показатель роста благосостояния.

Ключевые слова: экономическая производительность, предельная полезность, общая факторная, многофакторная, капитал, труд, затраты, выпуск, благосостояние.

\section{Current problems.}

The common notion of productivity is defined as the ratio of output to resources expended. The productive capacity of the economy, the productive capacity of nations is a much broader, multidimensional process. It reflects the general state of the economy, the efficiency of use of all resources, the nature and level of the institutional environment, the quality of human and social capital and so on. Efficient tool for that investigation is a total and multifactor productivity approaches.

The aim of the article. The fathers of economics paid great attention to the problem of creation and distribution of wealth, welfare of nations, determining the causes, nature, factors influencing these processes. Particular attention was paid to the efficient use of land, labour, capital. Among the main prerequisites for the economic capacity of the nation were the natural and geographical environment, the level of development of material and spiritual culture, the division of labour, international trade and others. At the same time, in particular, A. Smith, stressed that "the greatest improvement in the productive powers of labour, and the greater part of the skill, dexterity, and judgement with which it is any where directed, or applied, seem to have been the effects of the division of labour" (Smith 2001, 11). Smith mainly considered the firm (factory, manufacture) from the point of view of the division of labour (organic and heterogeneous manufacture), as the main factor in productivity growth. J. St. Mill analysed productivity through the prism of property relations and the cooperative nature of the social institution, dividing the productivity of the worker and the manager depending on their ownership of the means of production (Witztum 2012, 342343). Mill distinguished simple cooperation, when workers carried out joint activities in the process of producing one product (vertical relations), and complex cooperation, when different products are produced for exchange (horizontal relations). The scale, size of the firm, its limits (boundaries) are determined by Mill, the following components: technological conditions, the impact of distribution relations on productivity, the transnational nature of competition and the evolution of human nature (ethology). J.M. Keynes critically evaluated the category of wealth, its dynamics and structure in the definitions of classical economists, in particular, noting the descriptive nature of their interpretations (Keynes 2007, 43).

J. Turgot, J. H. von Thünen, T. Malthus considered the problems of productivity in the narrow sense, mainly limited to the productive capacity of agriculture. The law of declining productivity of the agricultural sector (soil) was formulated. The main task of current research is to use creative legacy of classical representatives in order to improve economic productivity. 


\section{Important research results. \\ Theory of marginal utility (productivity)}

Over time, the issue of wealth was transformed into a standard category of gross domestic product, while the issues of its generation were localised by the competitiveness of nations (Porter, 1990) and by the study of productivity of two main factors: labour and capital. In fact, during the second half of the XX century and at the beginning of the XXI century the productive capacity of a nation has been grounded mainly upon models of total factor productivity (TFP) or multifactor productivity (MFP).

To better understand these complex categories, let us consider the basic principles and concepts with reference to the theory of marginal utility (productivity) in the context of the marginalism paradigm that led to the second revolution in economics. Measuring marginal productivity is carried out gradually in several steps. First, the general formula of marginal physical productivity is determined:

$\mathrm{MPP}_{\mathrm{n}}=\mathrm{TPP}_{\mathrm{n}}-\mathrm{TPP}_{\mathrm{n}-1}$,

where $\mathrm{MPP}_{\mathrm{n}}$ is a marginal physical productivity of the $\mathrm{n}$-th unit of labour;

$\mathrm{TPP}_{\mathrm{n}}$ is a total physical productivity of the $\mathrm{n}$-th number of workers;

$\mathrm{TPP}_{\mathrm{n}-1}$ is a total physical productivity of the $\mathrm{n}-1$ unit of workers.

Marginal physical productivity means an increase in output caused by one factor of productivity while the remaining factors are unchanged. Illustration. Six workers produce 120 quintals of wheat. If another (seventh) worker is involved in production, the wheat harvest should total 140 quintals. In this case, the maximum physical productivity of an additional employee is 20 quintals $(140-120=20)$. At the same time, there may be situations when the seventh employee may have lower productivity (lack of additional equipment, lack of experience, physical capabilities, etc.), then the question arises whether it is feasible or not to attract an additional unit of labour in the context of marginal utility theory.

Marginal revenue productivity is defined as an increase in total revenue due to the attraction of a unit of additional factor upon the invariability of other factors. Suppose that 1 worker produces wheat resulting in revenue of $\$ 50$. Another worker is hired, and as a result the revenue increases to $\$ 60$. In this case, the marginal revenue productivity the second worker equals $\$ 10$. $(60-50=10)$.

The value (cost) of marginal productivity is equal to the product of marginal physical productivity and the market price of the product.

$\mathrm{VMP}=\mathrm{MPP} \times \mathrm{AR}$,

where VMP is a value of marginal productivity;

MPP is a marginal physical productivity;

$\mathrm{AR}$ is an average revenue (market price of the product).

If the market price of 1 quintal of wheat is $\$ 10$, and the marginal physical productivity of the 1 st additional worker is 20 quintals of wheat, then the marginal productivity of the additional worker will be equal to $\$ 200$. $(20 \times 10=200)$.

\section{Total Factor Productivity and Multifactor Productivity}

Measuring of productivity is a complex process that has its own history, initiated, as noted above, by the fathers of economics (Malthus, Smith, Marshall, etc.). In modern researches such aggregate indicators as a total factor productivity (TFP) and a multifactor productivity (MFP) prevail. Total Factor Productivity is measured by combining the effects of all the resources used in the production of goods and services (labour, capital, materials, energy, etc.) and dividing it into the output;utilizes more than a single factor. Multifactor productivity is the ratio of total output to a subset of inputs. A subset of inputs might consist of only labour and materials or it could include capital. MFP is the residual contribution to output growth of an industry or economy after calculating the contribution from all its factor inputs (Camus 2007, 21,182).

The OECD provides a tabular version for measuring the performance of essential elements of the economic system (table 1). 
Table 1. Measuring the productivity of the economic system

\begin{tabular}{|l|l|l|l|l|}
\hline Type of output & \multicolumn{4}{|c|}{ Type of input measure } \\
\cline { 2 - 5 } & Labour & Capital and & $\begin{array}{l}\text { Capital } \\
\text { labour }\end{array}$ & $\begin{array}{l}\text { Capital, labour } \\
\text { and intermediate } \\
\text { inputs (energy, } \\
\text { materials, } \\
\text { services) }\end{array}$ \\
\hline Gross output & $\begin{array}{l}\text { Labour } \\
\text { productivity } \\
\text { (based on gross } \\
\text { output) }\end{array}$ & $\begin{array}{l}\text { Capital } \\
\text { productivity } \\
\text { (based on gross } \\
\text { output) }\end{array}$ & $\begin{array}{l}\text { Capital-labour } \\
\text { MFP (based on } \\
\text { gross output) }\end{array}$ & $\begin{array}{l}\text { KLEMS* } \\
\text { multifactor } \\
\text { productivity }\end{array}$ \\
\hline Value added & $\begin{array}{l}\text { Labour } \\
\text { productivity } \\
\text { (based on value } \\
\text { added) }\end{array}$ & $\begin{array}{l}\text { Capital } \\
\text { productivity } \\
\text { (based on value } \\
\text { added) }\end{array}$ & $\begin{array}{l}\text { Capital-labour } \\
\text { MFP (based on } \\
\text { value added) }\end{array}$ & \\
\hline Single factor productivity measures & Multifactor productivity measures \\
\hline
\end{tabular}

* The model has resulted from the work of a consortium of 16 research, analytical and statistical organisations from different EU countries established in 2003. (the project has been titled EUKLEMS)

Source: Measuring productivity. Measurement of aggregate and industry-level productivity growth. Paris, 2001, p. 12.

The OECD methodology examines key single-factor (aggregated) indicators of labour and capital productivity, considering total output and costs and, most importantly, the value added, which reflects the real increase in the welfare of the nation. This creates the possibility of a separate analysis of productivity of both labour and capital, to carry out their synthesis based on multifactoriality and finally take into account the full range of factors based on the KLEMS model. A database of comparable statistics at the industry level is being developed to analyse the relationship between skills growth, technological progress and innovation, on the one hand, and productivity, on the other. An important unit of measurement of the productivity of the nation (country, national economy) is also the total factor productivity (TFP). It is grounded on the CobbDouglas production function with its parameters reflecting the contribution of two main factors labour and capital - to the country's GDP growth.

$\mathrm{Ln} \mathrm{TFP}=\ln \mathrm{Y}-\alpha \ln \mathrm{L}-(1-\alpha) \ln \mathrm{K}$,

where TFP is a total factor productivity;

$\mathrm{Y}$ - output of GDP;

$\alpha$ is the labour (wages) share in the GDP;

$1-\alpha$ is the capital share in the GDP;

$\mathrm{L}$ - labour;

$\mathrm{K}$ - capital.

The dynamic aspect involves determining the rate of the TFP growth defined as:

$\mathrm{p}_{\mathrm{t}}=\mathrm{dY}_{\mathrm{t}} / \mathrm{dt}-\alpha \mathrm{dL}_{\mathrm{t}} / \mathrm{dt}-(1-\alpha) \mathrm{dK}_{\mathrm{t}} / \mathrm{dt}$,

where $\mathrm{p}_{\mathrm{t}}$ is the rate of TFP growth;

$\mathrm{Y}_{\mathrm{t}}$ is output (GDP),

$\mathrm{dY}_{\mathrm{t}} / \mathrm{dt}$ is the rate of output growth,

$\mathrm{L}$ is the labour input,

$\mathrm{K}$ is the capital input,

$\alpha$ is the share of wages in the national GDP, 
$\mathrm{t}$ is the time required for economic measurements.

The logarithmic version of TFP growth (dynamics) is described as follows:

$\mathrm{p}_{\mathrm{t}}=\mathrm{d} \ln \mathrm{Y}_{\mathrm{t}} / \mathrm{dt}-\alpha \mathrm{d} \ln \mathrm{L}_{\mathrm{t}} / \mathrm{dt}-(1-\alpha) \mathrm{dlnK}_{\mathrm{t}} / \mathrm{dt}$

(Wolff 2014, 134,137).

In addition to this basic formula, there are a number of methods for determining TFP: empirically based quantitative indices, in particular, the hyperbolic Diewert index, econometric methods, stochastic boundary element methods, operating environment analysis, and so on. Exploring the total factor productivity, the authors also take into account such factors as innovation, education, market efficiency, infrastructure, institutions (Kim, Loayza 2019, 6-10).

In the framework of European cohesion policy, it is important to equalize productivity levels between different regions, divided into four categories: frontier regions, catching-up regions, keeping pace regions and diverging regions. Frontier regions were the regions with the highest level of productivity in each country, and the population of the region amounted to $10 \%$ of the total population. Catching-up regions have reduced the gap in productivity levels vis-à-vis Frontier regions during the period of consideration. Keeping pace regions have maintained the productivity level gap of $(++5 \%)$ vis-à-vis frontier regions. Diverging regions have increased the productivity gap vis-à-vis frontier regions. (table 2).

Table 2. Contribution of the different regional productivity patterns to aggregate EU GDP and employment growth, 2000-2014

\begin{tabular}{|l|c|c|c|c|c|}
\hline & $\begin{array}{l}\text { Contribution } \\
\text { to EU GDP } \\
\text { growth }\end{array}$ & $\begin{array}{l}\text { Share of } \\
\text { EU GDP } \\
\mathbf{2 0 0 0}\end{array}$ & $\begin{array}{l}\text { Share of } \\
\text { EU GDP } \\
\mathbf{2 0 1 4}\end{array}$ & $\begin{array}{l}\text { Share of EU } \\
\text { Employment } \\
\mathbf{2 0 0 0}\end{array}$ & $\begin{array}{l}\text { Share of EU } \\
\text { Employment } \\
\mathbf{2 0 1 4}\end{array}$ \\
\hline $\begin{array}{l}\text { Frontier } \\
\text { regions }\end{array}$ & $32 \%$ & $22 \%$ & $24 \%$ & $18 \%$ & $19 \%$ \\
\hline $\begin{array}{l}\text { Catching-up } \\
\text { regions }\end{array}$ & $24 \%$ & $18 \%$ & $19 \%$ & $23 \%$ & $22 \%$ \\
\hline $\begin{array}{l}\text { Keeping } \\
\text { pace regions }\end{array}$ & $30 \%$ & $40 \%$ & $38 \%$ & $38 \%$ & $39 \%$ \\
\hline $\begin{array}{l}\text { Diverging } \\
\text { regions }\end{array}$ & $15 \%$ & $21 \%$ & $20 \%$ & $21 \%$ & $21 \%$ \\
\hline
\end{tabular}

Source: Bachtler J. et al. Towards cohesion policy 4.0. Structural transformation and inclusive growth. Regional studies policy impact books, 2019, Volume 1, Number 1, p. 23.

As can be seen from the table 2 almost 2/3 of the EU GDP and of its employment fall upon keeping pace and diverging regions. At the same time, they contributed only $45 \%$, to the EU economic growth during 2000-2014, while Frontier regions representing 19\% of employment provided for $32 \%$ of the EU economic growth rate and 24\% of the EU GDP in 2014. Catching-up regions show slow progress for a slight increase in the contribution to the EU GDP and a slight decrease in employment. Regions are also differentiated as mostly urban (urban), intermediate and mostly rural. Thus, rural regions among Diverging regions make up almost half (48\%), while they account for $42 \%$ within Catching-up regions. At the same time, the share of mostly urban regions is $25 \%$ in diverging regions and $40 \%$ in keeping pace regions.

In research, it is essential to compare the TFP of different countries, to identify trends in convergence or divergence in productivity levels. There are $\beta$ and $\sigma$ convergence (Wolff 2014, 6162). $\beta$-convergence is based on the fundamental principles of neoclassical growth theory and characterises mainly the convergence of indicators of less developed countries with industrialised ones in terms of economic development (new global convergence). At the same time, countries with a lower initial level of capital accumulation and a lower level of income accumulate capital faster than the average rate, while countries where the initial capital accumulation exceeded the average level slow down the rate of capital accumulation. 
$\sigma$-convergence means reducing inequalities in productivity and per capita income among the richest and poorest countries (Wolff 2014, 61-62; Jablonski 2010, 57-58).

The first and the second indicators may differ. The country may be approaching the growth rate of developed countries and even be ahead of the same. However, the gap in GDP per capita may increase.

The main indicators are the volume of GDP per capita, the human development index, indices and indicators of sustainable development, etc. If a number of countries have the same initial conditions and show close convergence rates, this process is called club or group convergence. A clear example of such convergence is the economic development of the so-called Asian tigers in the 70s (Singapore, Republic of Korea, Hong Kong, Taiwan) and in the 80s (Malaysia, Thailand, Indonesia, India) of the last century.

Productivity is measured, as noted, based on total factor productivity (TFP) or multifactor productivity (MFP) models. The starting points are economic growth models with an emphasis on the Solow balance, the Cobb-Douglas production function. Thus, productivity is a relative indicator, the basis of which in the narrow sense is the analysis of the contribution of two key factors-labour and capital-in the generation of national wealth. Thus, the Bank of England's model for determining total factor productivity uses two main factors - labour and capital. In a broad sense, the TFP and MFP models being not fundamentally different from each other use a much wider set of criteria and indicators. For example, the European KLEMS project (model) use such components as energy, materials, services in addition to labour and capital. Canadian experts offer a much wider range of indicators in the measuring of total factor productivity. In particular, we are talking about intermediate costs (materials, business services, loan capital), labour costs, renewable capital costs, inventories (material values), land resources, other natural resources (fish stocks, forests, oil fields, mines), environmental improvement, working capital, cash and other financial instruments, knowledge capital (education, innovation, R\&D, etc.), infrastructure capital (Koszerek et al. 2007, 1.)

Some studies use the methodology of differentiation of productivity into three approaches: labour productivity, multifactor productivity and public productivity or productivity of social services (table 3 ).

Table 3. Three approaches to measuring productivity

\begin{tabular}{|l|l|l|l|}
\hline Costs & $\begin{array}{l}\text { Labour } \\
\text { productivity }\end{array}$ & $\begin{array}{l}\text { Multifactor } \\
\text { productivity }\end{array}$ & Public productivity \\
& $\begin{array}{l}\text { Labour - hours of } \\
\text { work, number of } \\
\text { jobs, number of } \\
\text { employees }\end{array}$ & $\begin{array}{l}\text { The quality of labour } \\
\text { in the context of the } \\
\text { volume of production } \\
\text { from labour }\end{array}$ & $\begin{array}{l}\text { Labour - the } \\
\text { equivalent of full } \\
\text { employment or the } \\
\text { estimated amount of } \\
\text { labour }\end{array}$ \\
\hline & $\begin{array}{l}\text { Capital - capital } \\
\text { services index }\end{array}$ & $\begin{array}{l}\text { Capital - } \\
\text { consumption of fixed } \\
\text { capital }\end{array}$ \\
\hline & Total value added & Total value added & $\begin{array}{l}\text { Ontermediate - the } \\
\text { cost of intermediate } \\
\text { goods and services } \\
\text { value-based activity } \\
\text { with a qualitative }\end{array}$ \\
\hline Output & & & \\
\hline
\end{tabular}




\begin{tabular}{|l|l|l|l|}
\hline Scope & & assessment \\
\hline $\begin{array}{l}\text { The whole economy, } \\
\text { market sector, } \\
\text { industry in terms of } \\
\text { industries }\end{array}$ & $\begin{array}{l}\text { Market sector, } \\
\text { industry }\end{array}$ & $\begin{array}{l}\text { General public } \\
\text { services broken } \\
\text { down according to } \\
\text { the classification of } \\
\text { government services }\end{array}$ \\
\hline
\end{tabular}

Source: https://www.ons.gov.uk.

The table allows us to conclude that labour productivity is measured by the volume of production compared to the number of employees or the final indicator of total value added. The multifactor indicator consists of the total value added formed by the volume of production by labour, the volume of production by capital and the balance of Solow. Productivity of public services is measured by the total output where intermediate services are added to the multifactor indicator. This methodology allows carrying out economic and statistical observations of the dynamics of the main indicators of productivity of different hierarchical levels. An option of comparing the cost-output of V. Leontief is introduced for a more detailed analysis, which complements the theory and methodology of productivity study (Leontief 2006, 85-87).

\section{Productive capacity of the nation}

The productive capacity of the nation is a much broader concept than the productivity of the economy or its individual units. This concept resonates in some way with the concept of "competitive advantage of nations" introduced by M. Porter. Many factors that distinguish competitiveness, especially at the macro level, are directly linked to productive capacity. However, the analysis of productive capacity the focus goes not only and not so much to current state of affairs, on the one hand, that is crucial for the initial stage of the study. The term ability contains the potential for diversification, growth, has a certain mobilising, perspective orientation. In particular, A. Toynbee focuses on the positive sources of "new creative capacity" (Toynbee 1995, 20). On the other hand, the purely economic, technological (according to Porter) components are supplemented by nation-building ones such as anthropological, psychological, mental, socio-cultural, institutional, etc. Therefore, the theoretical foundations of the nation's productive capacity are based on a wide range of factors and processes that result into its economic potential and reveal the mechanisms and tools of its effective use.

A set of factors of national productivity is considered in a detailed version. These include, firstly, the accumulation of capital by attracting domestic and foreign investment; introduction of the newest technologies capable to modernise manufacture; organisation of production and technological processes comparable to the best world models. Secondly, they are deepening of the division and cooperation of labour in the system of network chains at the national and global levels at different stages of production, distribution, creating effective coordination mechanisms for prices, contracts, formal and informal agreements, communications, trust, reputation and more. Thirdly, they are about the development of production infrastructure (transport, energy, telecommunications); improvement of social infrastructure, including public institutions, nongovernmental organizations, business and social networks, etc. Fourthly, this means increasing the educational level and competence of those employed in the economy, which according to some calculations, is pivotal in increasing productivity (Nelson 2006).

Indirect productivity factors: support of civil liberties; openness to foreigners; positive relationships with subordinates; self-esteem, sense of personal competence; participation in public and national affairs; interpersonal trust and satisfaction with one's own life.

Experts also take into account the mental model of the nation consisting of definite and specific beliefs, preferences, conclusions and goals. This is a kind of mental map of the nation. There is a set of institutions, beliefs and guidelines that are either pro-innovative and create conditions for productivity and prosperity, or anti-innovative that inhibit progress and development. 
Thus, F. Hayek noted that the Anglo-Saxon legal system created better preconditions, a wider corridor of freedom for economic development and entrepreneurship than the continental one. Similarly, according to M. Weber and other researchers, Protestant ethics gave a huge impetus to undermine the feudal foundations and the rapid development of capitalist relations, productivity growth, capital, economy and the nation as a whole (Weber 1994, 56-57). In analysing the productive capacity of the Ukrainian nation, as well as other communities, an important component is the consideration of the business culture of the people. To this end, Lewis distinguishes three groups of business cultures: monoactive, polyactive, reactive. Ukrainian business culture tends to be polyactive characterised by: general planning, multitasking; flexibility in terms of working hours; non-punctuality, unpredictability of the schedule and rapid change of plans according to the degree of significance of an event, overlapping between the project, loose interpretation of facts, dominant collectivism, high power distance (distance between leader and subordinate), high desire to avoid uncertainty.

According to the calculations of the Federal Bank of St. Louis, the total productivity of factors of production in Ukraine was 0.48 in 1990 compared to the United States, and only 0.176 in 1999, which was due primarily to the transformation crisis after the collapse of the Soviet Union. Positive dynamics of overall performance was observed from 2000 to 2011, but the level of 1990 was never reached (0.35 compared to the United States in 2011). (Economic Research. Federal Reserve Bank St. Louis, 2020).

These indicators illustrate, firstly, the low level of productivity of Ukraine's economy, especially given the key indicators: GDP per capita and the average wage. Secondly, there is a clear trend of volatility, instability of economic processes, vulnerability to internal and external shocks. Third, the weak productivity of the main factors of production - labour and capital with a high level of education of the workforce, the presence of one of Europe's largest engineering corps and scientists - highlights a component that has not yet been sufficiently formalised - the country's institutional system that is the main brake on stable economic progress.

\section{Conclusions}

The theoretical and methodological foundations of productivity are laid by the classical authors of economics, who considered these processes through the prism of the division and cooperation of labour, the relationship between the employee and the owner of the means of production. Over time, the focus has shifted on the productivity of the two main factors of production, labour and capital, based on the Cobb-Douglas production function, taking into account the Solow balance and factors such as innovation, education, market efficiency, infrastructure, institutions, and so on. On this basis, the main indicators of productivity nowadays have become the total factor productivity and multifactor productivity. At the same time, the creative heritage of Toynbee, Porter and others indicates an expanded interpretation of productivity as the productive capacity of individual nations and countries. In this case, in addition to purely economic, technological nation-building components other ones such as anthropological, psychological, mental, socio-cultural, institutional, etc. are considered.

\section{References}

1. Acemoglu, Daron and Robinson, James A. Why nations fail. The Origins of Power, Prosperity, and Poverty, trans from Engl. Kyiv: Nash format (In Ukrainian).

2. Agostino, Mariarosaria et. al. 2020. “ Institutional quality and firms' productivity in European regions". Regional studies 54: 1275-1288.

3. Agrell, Per J., Wikner, Joakim. 1996. "A coherent methodology for productivity analysis employing integrated partial efficiency". International Journal of Production Economics 46-47: 401-411. 
4. Bachtler, John. et al. 2019. "Towards cohesion policy 4.0. Structural transformation and inclusive growth". Regional studies policy impact books 1, 1: 17-28.

5. Barath, Lajos, Ferto, Imre. 2016. "Productivity and Convergence in European Agriculture". Discussion papers MT-DT 26: 3-34.

6. Castels, Manuel et al. 2017. Another economy is possible. Culture and economy in a time of crisis. Malden: Polity.

7. Convergence of economic models of Poland and Ukraine. 2010. Edited by Dmytro Lukyanenko, Viktor Chuzhykov, Michal G. Wozniak. Kyiv: KNEU (In Ukrainian).

8. Deleidi, Matteo, Meloni, Walter P. \& Stirati, Antonella. 2020. "Tertiarization, productivity and aggregate demand: evidence-based policies for European countries". Journal of Evolutionary Economics \#30: 1429-1465.

9. Economic Research. Federal Reserve Bank St. Louis. Accessed October 30, 2020. https://research.stlouisfed.org/fred2/series/CTFPPPUAA669NRUG\#

10. Global Productivity. Trends, Drivers, and Policies. 2020. Edited by Alistair Dieppe. Washington DC: World Bank.

11. Groth, Charlotta, Gutierrez-Domenech, Maria and Srinivasan, Sylaja. 2003. Measuring total factor productivity for the United Kingdom. Bank of England. Accessed October 30, 2020. http://www.bankofengland.co.uk/publications/Documents/quarterlybulletin/qb040106.pdf

12. Hideaki, Aoyama, Hiroshi, Yoshikawa, Hiroshi, Iyetomi., Yoshi, Fujiwara. 2008. "Productivity Dispersion: Facts, Theory, and Implications". The Research Institute of Economy, Trade and Industry. Accessed October 30, 2020. http://www.rieti.go.jp/en/

13. Keynes, John M. 2007. The general theory of employment, interest and money. The selected works, trans. from Engl. Moscow: Eksmo. (In Russian).

14. Kim, Jungsuk and Park, Jungsoo. 2017. "The Role of Total Factor Productivity Growth in Middle income Countries". ADB Economics Working Paper Series, 527: 3-29.

15. Kim, Young Eun, Loayza, Norman V. 2019. "Productivity Growth. Patterns and Determinants across the World". Policy Research Working Paper. Development Economics 8852: $1-69$.

16. Koszerek, Douglas, Havik, Karel, McMorrow, Kieran, Röger, Werner and Schönborn, Frank. 2007. "An overview of the EU KLEMS Growth and Productivity Accounts". European Economy. Economic Papers 290: 105.

17. Leontief, Vasiliy. 2006. The selected works in 3 vol. vol. 2. Special investigations on the ground of "input-output". Moscow: Economica. (In Russian).

18. Martini, Barbara, Giannini, Massimo. 2020. "Regional wage and productivity in Italy: a spatio-temporal analysis". Spatial economic analysis, 15:392-412.

19. Mill, John S. 2007. Principles of Political Economy with some of their applications to social philosophy, trans. from Engl. Moscow: Eksmo (In Russian).

20. Morris, Ian. 2018. Why the West rules - for now. The Patterns of history and what they reveal about the future, trans from Engl. Kyiv: Klio (In Ukrainian).

21. Nelson, Richard. 2006. "What makes an economy productive and progressive? What are the needed institutions?" Working Paper Series: 24. ONS Productivity Handbook. A Statistical Overview and Guide. 2007. Edited by Dawn Camus. New York: Palgrave Macmillan.

22. Porter, Michael E. 1990. Competitive Advantage of Nations. Boston: Harvard Business Review.

23. Productivity Growth in the Digital Age. 2019. Paris: OECD. Accessed October 30, 2020. www.oecd.org/going-digital.

24. Schwab, Klaus. 2016. The Fourth Industrial Revolution. Geneva: World Economic Forum.

25. Smith, Adam. 2001. Inquiry into the nature and causes of the wealth of nations, trans. from Eng. Kyiv: Port-Royal. (In Ukrainian).

26. Spence, Michael. 2013. The Next Convergence: The Future of Economic Growth in a Multispeed World, trans. from Engl. Moscow: Publishing Gaydar institute (In Russian). 
27. Tarscott, Don and Tarscott, Alex. 2018. Blockchain revolution. How the Technology behind bitcoin and other cryptocurrencies is changing the World. New York: Portfolio/Penguin.

28. The Economics of Productivity. 2009. Edited by Dawn W. Jorgenson. Cheltenham: Edward Elgar Publishing Limited.

29. Total economy data base key findings. July 2020. Accessed October 30, 2020 www.conferenceboard.ca

30. Toynbee, Arnold J. 1995. A Study of history, trans. from Engl. Kyiv: Osnovy. (In Ukrainian).

31. Weber, Max. 1994. The Protestant Ethic and the Spirit of Capitalism, trans. from German. Kyiv: Osnovy. (In Ukrainian).

32. Witztum, Amos. 2012. "The firm, property rights and methodological individualism: some lessons from J. St. Mill. - Journal of economic methodology 19, 4: 339-356.

33. Wolff, Edward N. 2014. Productive convergence. Theory and evidence. Cambridge: Cambridge University Press. 